\title{
Stimulation by Thyroid-stimulating Hormone and Graves' Immunoglobulin G of Vascular Endothelial Growth Factor mRNA Expression in Human Thyroid Follicles In Vitro and fit mRNA Expression in the Rat Thyroid In Vivo
}

\author{
Kanji Sato, * Kazuko Yamazaki, ${ }^{\$}$ Kazuo Shizume," Yoshio Kanaji, ${ }^{\S}$ Takao Obara, ${ }^{\ddagger}$ Kazuoki Ohsumi, ${ }^{1}$ Hiroshi Demura, * \\ Sachiko Yamaguchi, ${ }^{\star *}$ and Masabumi Shibuya** \\ Departments of $*$ Medicine and ${ }^{\ddagger}$ Surgery, Institute of Clinical Endocrinology, Tokyo Women’s Medical College, Tokyo 162; ${ }^{8}$ Kanaji \\ Hospital, Tokyo 115; "Research Institute for Growth Science in Japan, Tokyo; 'Mitsubishi-Yuka BCL, Tokyo 174; and **Department of \\ Genetics, Institute of Medical Science, University of Tokyo, Tokyo 108, Japan
}

\begin{abstract}
To elucidate the pathogenesis of thyroid gland hypervascularity in patients with Graves' disease, we studied the expression of mRNAs for vascular endothelial growth factor (VEGF) and its receptor, Flt family, using human thyroid follicles in vitro and thiouracil-fed rats in vivo. Human thyroid follicles, cultured in the absence of endothelial cells, secreted de novo-synthesized thyroid hormone in response to thyroid-stimulating hormone (TSH) and Graves' IgG. The thyroid follicles produced $V E G F$ mRNA but not $f t-1$ mRNA. The expression of $V E G F$ mRNA was enhanced by insulin, tumor-promoting phorbol ester, calcium ionophore, dibutyryl cAMP, TSH, and Graves' IgG. When rats were fed thiouracil for 4 wk, their serum levels of TSH were increased at day 3. VEGF mRNA was also increased on day 3 , accompanied by an increase in $f t$ family ( $f t-1$ and $K D R$ / $f l k-1)$ mRNA expression. These in vitro and in vivo findings suggest that VEGF is produced by thyroid follicles in response to stimulators of TSH receptors, via the protein kinase $A$ and $C$ pathways. VEGF, a secretable angiogenesis factor, subsequently stimulates Fit receptors on endothelial cells in a paracrine manner, leading to their proliferation and producing hypervascularity of the thyroid gland, as seen in patients with Graves' disease. (J. Clin. Invest. 1995. 96:1295-1302.) Key words: hypervascularity $\bullet$ angiogenesis - angiogenesis factors • Graves' disease • endothelial cells
\end{abstract}

\section{Introduction}

In patients with Graves' disease, the thyroid gland is hypervascular, and a venous hum is usually heard (1). Although these phenomena are pathognomonic clinical features of Graves' disease, their pathogenesis remains to be elucidated.

This work has appeared in abstract form (11-14 November 1993. The Abstracts of the 66th Meeting of the American Thyroid Association, T74 [No. 145] Tampa, FL)

Address correspondence to Dr. Masabumi Shibuya, Department of Genetics, Institute of Medical Science, University of Tokyo, 4-6-1 Shirokane-dai, Minato-ku, Tokyo 108, Japan. Phone: 81-3-5449-5550; FAX: 81-3-5449-5425.

Received for publication 31 October 1994 and accepted in revised form 15 May 1995.

J. Clin. Invest.

(C) The American Society for Clinical Investigation, Inc.

0021-9738/95/09/1295/08 \$2.00

Volume 96, September 1995, 1295-1302
Recently, a number of in vivo angiogenesis factors have been reported $(2,3)$. However, TGF- $\alpha$, TGF- $\beta$, TNF- $\alpha$, angiogenin, and PGE have little or no mitogenic effect on cultured endothelial cells in vitro. Although acidic fibroblast growth factor, basic fibroblast growth factor (bFGF), and platelet-derived endothelial growth factor can stimulate both vascular endothelial growth in vitro and angiogenesis in vivo, they lack a signal peptide, implying that these factors may become available to their target cells only after cell death $(2,3)$.

In contrast, vascular endothelial growth factor (VEGF), ${ }^{1}$ a secretable factor that preferentially stimulates the proliferation of endothelial cells, does have a signal peptide, implying that it is a physiological angiogenesis factor $(4,5)$. Recently, a receptor $f t$, fms-like tyrosine kinase (now designated as $f t-1$ ) and an $f t$-related kinase $K D R / f l k-1(6,7)$, have been identified as the receptors for VEGF $(7,8)$. The binding sites for VEGF are localized exclusively on endothelial cells (9), and binding to the receptor is followed by proliferation of the cells $(3-11)$. On the assumption that VEGF from thyroid parenchymal cells and Flt family on endothelial cells might be involved in the thyroid gland hypervascularity seen in patients with Graves' disease, we studied whether the gene for VEGF is expressed in human thyroid cells, and whether the levels of VEGF mRNA are regulated by thyrotropic factors, using human thyroid follicles in suspension culture, in which thyroid follicles incorporate ${ }^{125} \mathrm{I}$ and secrete de novo-synthesized thyroid hormones into the culture medium in response to thyroid-stimulating hormone (TSH) and human chorionic gonadotropin (12-14). Furthermore, we studied the in vivo expression of $V E G F$ and $f t$ family mRNAs in thiouracil-fed rats, in which thyroid epithelial and endothelial cell proliferation has been examined in detail histologically (15).

\section{Methods}

Sources of materials and Graves' IgG. Culture media (F-12, RPMI 1640 ) were obtained from Gibco Laboratories, Grand Island, NY. FCS was obtained from Filtron Ltd., Brooklyn, Australia. Collagenase (type IV ), bovine TSH, thiouracil, A23187, dibutyryl cAMP, H7, and tumorpromoting phorbol ester (12-O-tetradecanoyl-phorbol-13-acetate, TPA) were obtained from Sigma Chemical Co., St. Louis, MO. IgG from patients with untreated Graves' disease (Graves' IgG) was obtained, as described previously (14). Usually, $6 \mathrm{ml}$ serum was dialyzed against

1. Abbreviations used in this paper: flt, fms-like tyrosine kinase or VEGF receptor; GAPDH, glyceraldehyde 3-phosphate dehydrogenase; TPA, 12-O-tetradecanoylphorbol-13-acetate; TSH, thyroid-stimulating hormone; TSI, thyroid-stimulating Ig; VEGF, vascular endothelial growth factor. 
$10 \mathrm{mM}$ Tris-HCl buffer ( $\mathrm{pH}$ 7.4) and applied to a protein A-Sepharose column. After eluting with $0.1 \mathrm{M}$ glycine- $\mathrm{HCl}$ buffer ( $\mathrm{pH} 3.0$ ), the eluate was immediately neutralized with $1 \mathrm{~N} \mathrm{NaOH}$ and then extensively dialyzed against $0.9 \% \mathrm{NaCl}$ solution. Finally, the eluates were dialyzed against culture medium and sterilized by filtering through a $0.45-\mu \mathrm{m}$ filter (Millipore, Corp., Bedford, MA). The samples were stored at $4^{\circ} \mathrm{C}$.

Preparation of thyroid follicles. Patients with Graves' disease scheduled for surgery were given iodine supplements for 8-14 d before surgery. Informed consent was obtained from all subjects. The thyroid tissue ( $15-30 \mathrm{~g}$ ) obtained by subtotal thyroidectomy from these patients was minced with scissors into small pieces $(3 \times 3 \times 3 \mathrm{~mm})$ in $10 \mathrm{ml}$ icecold $\mathrm{Ca}^{2+}, \mathrm{Mg}^{2+}$-free HBSS. The dissected thyroid tissue was filtered through nylon mesh ( 80 mesh) and washed with $10 \mathrm{ml}$ HBSS. The dissected thyroid tissues were digested with $0.3 \mathrm{mg} / \mathrm{ml}$ collagenase (type IV) and $5 \mathrm{mg} / \mathrm{ml}$ dispase (Godo Shusei Co., Tokyo, Japan) in HBSS at $32^{\circ} \mathrm{C}$ for $30 \mathrm{~min}$, and thyroid follicles were obtained as described previously $(12,13)$.

The thyroid follicles were cultured in $1 \mathrm{ml} \mathrm{F-12/RPMI} 1640$ (1:1) medium supplemented with various concentrations of FCS $(0-10 \%)$ in 24-multiwell dishes ( $\sim 300$ follicles $/ 2-\mathrm{cm}^{2}$ well $)$. In several experiments, the follicles were cultured in serum-free F-12/RPMI 1640 (1:1) medium supplemented with BSA $(2 \mathrm{mg} / \mathrm{ml})$, bovine insulin $(5 \mu \mathrm{g} / \mathrm{ml})$, hydrocortisone $\left(10^{-8} \mathrm{M}\right)$, bovine transferrin $(5 \mu \mathrm{g} / \mathrm{ml})$, and $\mathrm{NaI}\left(10^{-8}\right.$ $M)$, as described previously $(13,14)$. The dishes were pretreated with agarose to prevent attachment of thyroid follicles (16).

When thyroid hormonogenesis was studied, ${ }^{125} \mathrm{I}(\sim 15,000 \mathrm{cpm})$ was added after culturing for $5 \mathrm{~d}$, and after an additional $3 \mathrm{~d}$ of culture, ${ }^{125}$ I incorporated into the thyroid follicles and organic ${ }^{125} \mathrm{I}$ released into the culture medium were counted as described previously. Thin-layer analysis revealed that organic ${ }^{125} \mathrm{I}$ released into the medium was mainly $\left.{ }^{125} \mathrm{I}\right]$ thyroxine $\left(\mathrm{T}_{4}\right)$ and $\left[{ }^{125} \mathrm{I}\right]$ triiodothyronine $\left(\mathrm{T}_{3}\right)(17)$.

In vitro studies of VEGF mRNA expression in human thyroid follicles. To study the regulation of VEGF mRNA expression in thyroid follicles, $\sim 30,000$ follicles were cultured in $10 \mathrm{ml}$ F-12/RPMI 1640 medium supplemented with $1 \%$ FCS for $3 \mathrm{~d}$. Then, the thyroid follicles were treated with insulin, TPA, TSH, or IgG from patients with active Graves' disease for 0-3 d, as described in each experiment. In some experiments, thyroid follicles were cultured in medium containing various concentrations of FCS $(0-10 \%)$ or serum-free F-12/RPMI 1640 medium supplemented with insulin and TSH $(10 \mu \mathrm{U} / \mathrm{ml})$. Usually, 10$\mathrm{cm}$ dishes were pretreated with agarose to culture thyroid follicles in suspension. After appropriate culture periods, the thyroid follicles were centrifuged and total RNA was extracted as reported previously (18).

In several experiments, thyroid follicles were cultured in agaroseuntreated dishes. The thyroid follicles became attached to the dishes on the following day and became flattened on days 5-7 when RNA was prepared.

VEGF concentration in conditioned medium. Human thyroid follicles were cultured in F-12/RPMI 1640 medium supplemented with 1\% FCS for $3 \mathrm{~d}$ and subsequently treated with bovine insulin for $6 \mathrm{~h}$. After centrifugation at $3,000 \mathrm{rpm}$ for $10 \mathrm{~min}$, the conditioned medium was stored at $-20^{\circ} \mathrm{C}$.

Polyclonal anti-human VEGF antiserum was obtained by immunizing rabbits with a subcutaneous injection of human $\left[{ }^{14} \mathrm{Cys}\right]\left[{ }^{15} \mathrm{Tyr}\right]$ VEGF (1-13 residues) conjugated with bovine thyroglobulin. The antibody cross-reacted with recombinant human VEGF equipotently with $\left[{ }^{14} \mathrm{Cys}\right]\left[{ }^{15} \mathrm{Ty}\right.$ ] VEGF ( $1-13$ residues). Using [ $\left.{ }^{125} \mathrm{I}\right]$ VEGF (sp act, 55 $\mathrm{TBq} / \mathrm{mmol}$; Amersham International, Little Chalfont, UK) as a tracer and recombinant human VEGF otbained from PeproTech, Inc. (Rocky Hill, NJ) as standard, radioimmunoassay was conducted in $0.3 \mathrm{ml}$ phosphate buffer $(50 \mathrm{mM}, \mathrm{pH} 7.4)$ containing $0.1 \%$ BSA, $0.1 \%$ Tween 20 , and $0.02 \% \mathrm{NaN}_{3}$. The sensitivity of the assay was $0.3 \mathrm{ng} / \mathrm{ml}$.

In vivo expression of VEGF and ft family mRNAs in thiouracil-fed rats. 8-wk-old male Wistar-Imamichi rats were purchased from Shizuoka Laboratories Animal Center, Shizuoka, Japan. The rats were fed rat chow with a low iodine content and containing $0.25 \%$ thiouracil. Control rats were fed normal rat chow. After $1,3,7,14,21$, and $28 \mathrm{~d}$, the rats were anesthetized with ether. After blood had been taken from the abdominal vein, the thyroid gland was removed from the trachea and dissected with scissors in an ice-cold denaturing solution (4 M guanidinium thiocyanate) (19). Then thyroid pieces were homogenized using a homogenizer with a Teflon pestle. RNA from four to six rats was combined and used for Northern blot analysis.

Serum $T_{3}$ and $T_{4}$ were measured using immunoradiometric assay kits (Eiken Immunochemical Co., Tokyo, Japan). Rat TSH was measured using a rat TSH ${ }^{125} \mathrm{I}$ assay kit (PRA.548; Amersham Life Science, Tokyo, Japan). To avoid interassay variance, all samples were determined simultaneously.

Northern blot analysis of mRNAs for VEGF, flt-1, and KDR/flk-1. Total cellular RNA was isolated by guanidinium thiocyanate and phenol extraction according to the method of Chomczynski and Sacchi (19). $10 \mu \mathrm{g}$ of total RNA was electrophoresed on $1 \%$ agarose-formaldehyde gels containing ethidium bromide. RNA samples were transferred onto nylon membranes and then hybridized with human VEGF cDNA spanning nucleotide $0.6 \mathrm{~kb}(6,20,21)$, rat $V E G F \quad 0.5-\mathrm{kb}$ cDNA, rat $f t-1$ 1.2-kb cDNA, or rat $K D R / f l k-1$ 1.2-kb cDNA (21) labeled with [ $\alpha$ ${ }^{32} \mathrm{P}$ ] deoxy-CTP by the random primer method. The filters were washed three times ( $30 \mathrm{~min}$ each) to a stringency of $0.1 \times$ sodium citrate, $0.1 \%$ SDS at $55^{\circ} \mathrm{C}$ and exposed to X-omat film (Eastman Kodak, Rochester, NY) with an intensifying screen at $-70^{\circ} \mathrm{C}$. For comparison of RNA loading, the filters were rehybridized with ${ }^{32} \mathrm{P}$-labeled human $\beta$-actin or glyceraldehyde 3-phosphate dehydrogenase (GAPDH) cDNA ( supplied by Y. Murata, Research Institute for Environmental Medicine, Nagoya University, Nagoya, Japan) (22), as described previously (18).

Statistical analysis. Statistical analysis was performed by Student's $t$ test when two comparisons were made. Differences were considered significant at $P<0.05$.

\section{Results}

Effects of TSH, Graves' IgG, and FCS on thyroid function in cultured human thyroid follicles. As reported previously (12, 13), bTSH stimulated human thyroid follicles to incorporate ${ }^{125} \mathrm{I}$ and release organic ${ }^{125} \mathrm{I}$ into the culture medium in a concentration-dependent manner (Fig. 1, left). The minimal and maximal stimulatory effects of bTSH were obtained at 0.1 and 10 $\mu \mathrm{U} / \mathrm{ml}$, respectively.

Graves' IgG also stimulated thyroid function in a dosedependent manner (Fig. 1, right). The IgG was purified from $6 \mathrm{ml}$ serum and reconstituted in $6 \mathrm{ml}$ culture medium. It stimulated thyroid function at $20 \mu \mathrm{l} / \mathrm{ml}$ and produced a strong stimulation at $300 \mu \mathrm{l} / \mathrm{ml}$, whereas IgG obtained from normal subjects had no effect (Fig. 1, middle).

When thyroid follicles were cultured in medium containing various concentrations of FCS, TSH-induced thyroid function was impaired in a concentration-dependent manner (Fig. 2). TSH stimulated thyroid function maximally in serum-free medium supplemented with $0.2 \%$ BSA. Thyroid follicles cultured with FCS at low concentration (1\%) responded to bTSH but lost their responsiveness to TSH at higher concentrations (2.0$10 \%)$. Therefore, subsequent experiments were usually performed in medium containing $1 \%$ FCS or serum-free medium supplemented with $0.2 \%$ BSA.

VEGF $m R N A$ expression in monolayer thyrocytes and thyroid follicles in suspension culture. Thyroid follicles were cultured in serum-free medium supplemented with insulin and bTSH for $5 \mathrm{~d}$ with or without agarose coating. Thyroid follicles cultured in flasks without agarose coating became attached to the bottom and grew in a monolayer within $5 \mathrm{~d}$, whereas those in agarose-coated flasks grew in suspension. $V E G F$ mRNA was expressed to a greater extent in thyroid follicles than in mono- 


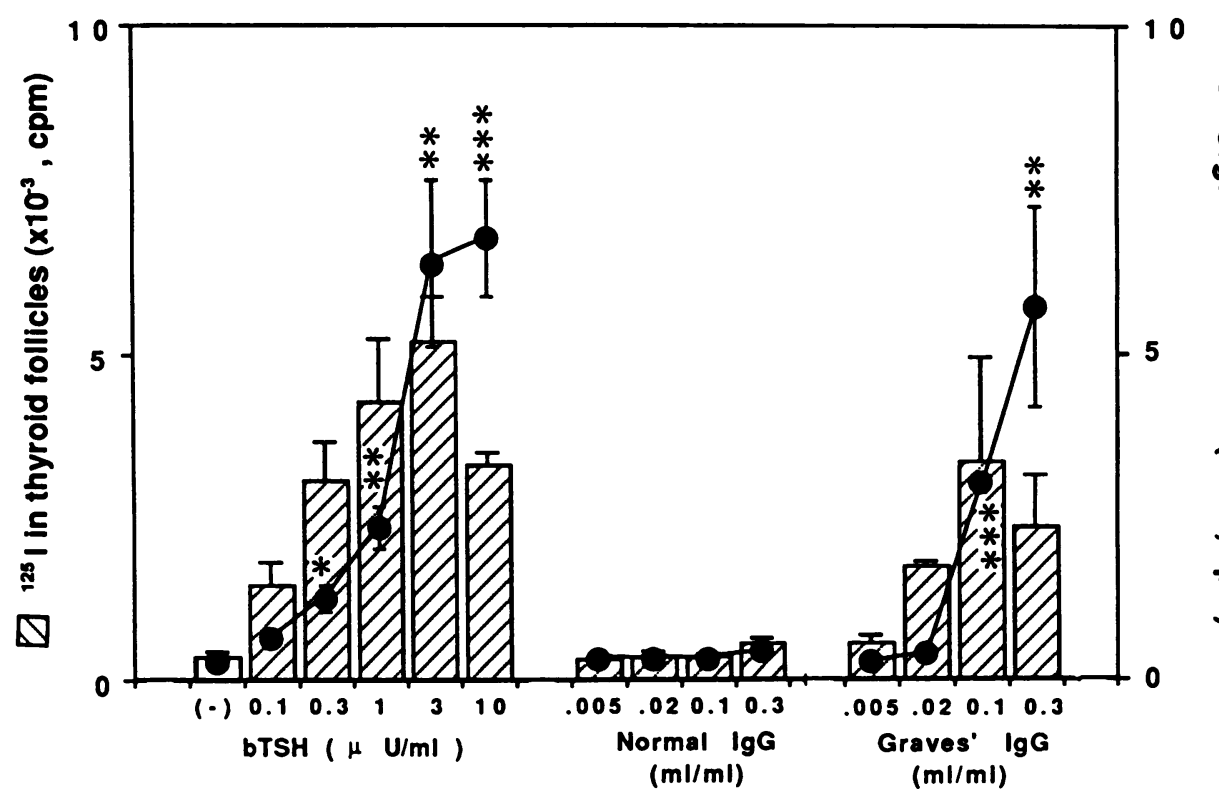

Figure 1. Effects of TSH and Graves' IgG on thyroid function in human thyroid follicles in suspension culture. Human thyroid follicles were cultured in 24-multiwell dishes containing 1 ml serum-free F-12/RPMI 1640 medium supplemented with $0.2 \%$ BSA, insulin $(5 \mu \mathrm{g} / \mathrm{ml})$, and various concentrations of bTSH (left), and IgG from a normal subject (middle) and a patient with active Graves' disease (right). On day $3,{ }^{125} \mathrm{I}(\sim 15,000$ cpm) was added, and after an additional $3 \mathrm{~d}$ of culture, ${ }^{125} \mathrm{I}$ in the thyroid follicles (columns) and organic ${ }^{125} \mathrm{I}$ released into the culture medium $(\bullet)$ were counted. Data are means of quadruplicate cultures. ${ }^{*} P<0.05, * * P$ $<0.01, * * * P<0.001$ layer cells (Fig. 3). Therefore, the following studies were performed using thyroid follicles in suspension culture.

Effect of insulin on VEGF mRNA expression and VEGF concentration in the conditioned medium. Insulin stimulated $V E G F$ mRNA expression in thyroid follicles in a time- and dose-dependent manner. The minimal stimulatory effect of insulin was observed at $0.04 \mu \mathrm{g} / \mathrm{ml}$, and it maximally increased the mRNA at $0.2 \mu \mathrm{g} / \mathrm{ml}$ (Fig. 4, upper panel). However, at a higher concentration $(25 \mu \mathrm{g} / \mathrm{ml}), V E G F$ mRNA expression was rather depressed. VEGF mRNA induced by insulin $(0.2 \mu \mathrm{g} / \mathrm{ml})$ was increased maximally at 2-3 h (Fig. 4, lower panel).

Basal VEGF concentration in the medium conditioned by thyroid follicles for $3 \mathrm{~d}$ was $4.4 \pm 1.2 \mathrm{ng} / \mathrm{ml}(n=3$, mean $\pm \mathrm{SD})$. Consistent with the mRNA level, treatment of thyroid follicles with insulin for $3 \mathrm{~d}$ increased the level of immunoreactive VEGF in the conditioned medium in a biphasic manner (insulin $0.2 \mu \mathrm{g} / \mathrm{ml}$, VEGF $7.8 \mathrm{ng} / \mathrm{ml} ; 1 \mu \mathrm{g} / \mathrm{ml}, 14.8 \mathrm{ng} / \mathrm{ml} ; 5 \mu \mathrm{g} / \mathrm{ml}$, $8.0 \mathrm{ng} / \mathrm{ml} ; 25 \mu \mathrm{g} / \mathrm{ml}, 6.4 \mathrm{ng} / \mathrm{ml}$; mean of duplicates), sug-

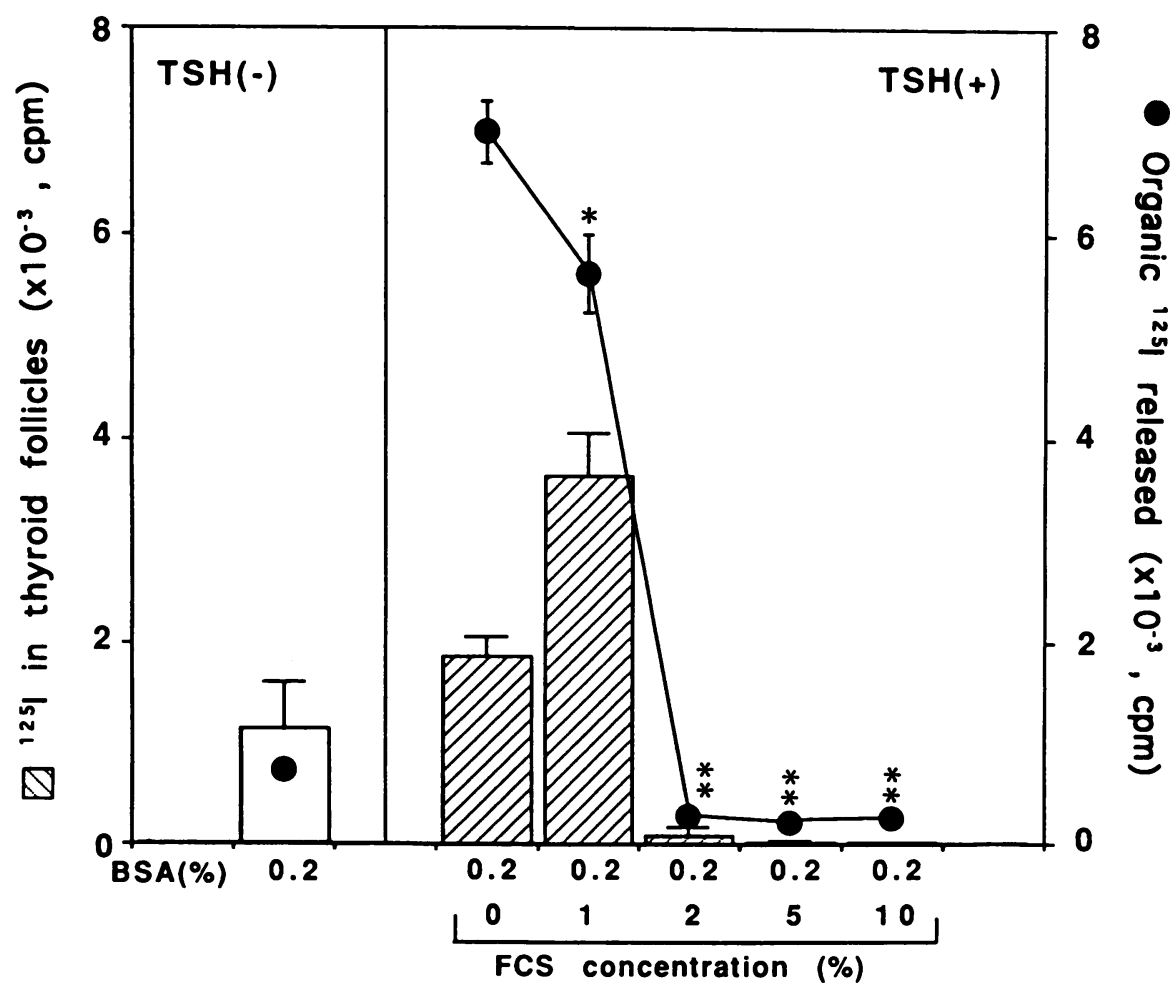

Figure 2. Effect of FCS concentration on thyroid function induced by TSH in cultured human thyroid follicles. Human thyroid follicles were cultured in $1 \mathrm{ml} \mathrm{F-12/RPMI} 1640$ (1:1) medium containing $0-10 \% \mathrm{FCS}$, in the presence or absence of bTSH $(10 \mu \mathrm{U} / \mathrm{ml})$, as described in Methods. After $5 \mathrm{~d}$ of culture,

${ }^{125} \mathrm{I}$ was added, and after an additional $3 \mathrm{~d}$ of culture, ${ }^{125} \mathrm{I}$ in the thyroid follicles (columns) and organic ${ }^{125}$ I released into the culture me$\operatorname{dium}(\bullet)$ were counted. Data are means \pm SD

$(n=4) . * P<0.01, * * P<0.001$. 


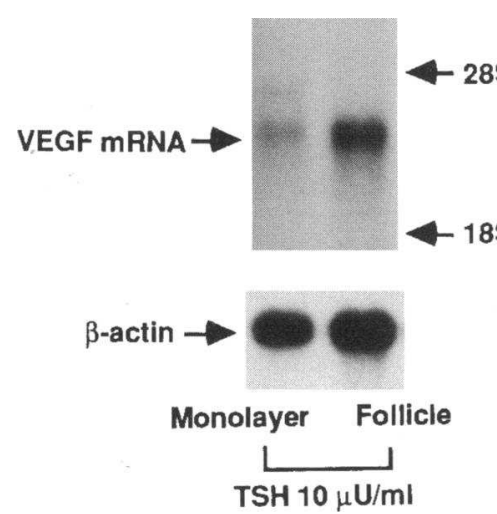

or thyroid follicles cultured in suspension (with coating), was subjected to RNA blot analysis with a human VEGF cDNA probe. The locations of $28 \mathrm{~S}$ and $18 \mathrm{~S}$ rRNAs are indicated by arrowheads. For comparison of RNA loading, a $\beta$-actin probe was hybridized to the same filter.

gesting that VEGF was secreted into the culture medium. A slight discrepancy between the levels of VEGF mRNA and of VEGF protein after stimulation with insulin might be due to a difference of degradation or of secretion rate of VEGF proteins in different concentrations of insulin.

Effect of protein kinase C stimulators on VEGF $m R N A$ expression. TPA, a potent protein kinase $\mathrm{C}$ activator, stimulated $V E G F$ mRNA expression in a time- and dose-dependent manner. TPA maximally stimulated $V E G F$ mRNA at $\sim 10^{-7}-10^{-6}$ $M$ (Fig. 5, upper panel), and the TPA-induced VEGF mRNA expression was increased maximally at $2-4 \mathrm{~h}$ incubation (Fig. 5, lower panel).

The calcium ionophore, A23187, also stimulated VEGF
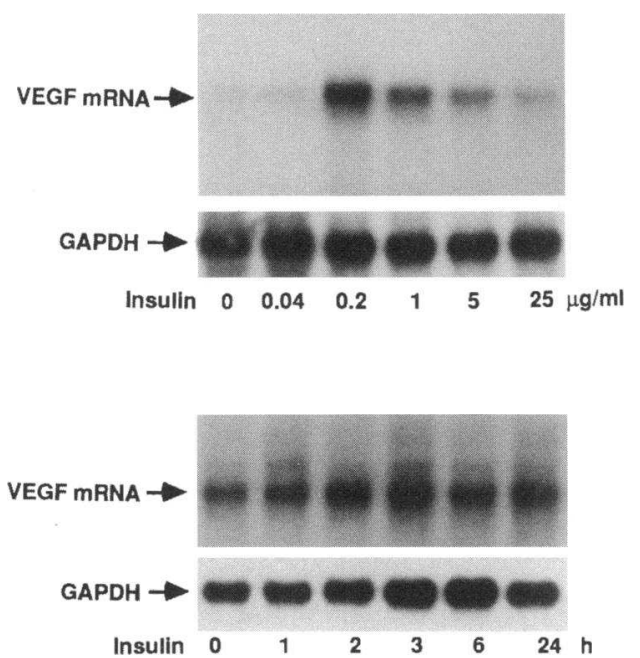

Figure 4. Effect of insulin on VEGF mRNA expression in thyroid follicles. Human thyroid follicles were cultured in medium containing $1 \%$ FCS for $3 \mathrm{~d}$ and subsequently treated with various concentrations of bovine insulin $(0.04-25 \mu \mathrm{g} / \mathrm{ml})$ for $6 \mathrm{~h}$ (upper panel). In the other experiment, after addition of bovine insulin $(0.2 \mu \mathrm{g} / \mathrm{ml})$, thyroid follicles were cultured for the indicated times, from $0-24 \mathrm{~h}$ (lower panel). Total RNA (10 $\mu \mathrm{g} /$ lane) was subjected to RNA blot analysis with a human VEGF cDNA probe. For comparison of RNA loading, GAPDH probe was hybridized to the same filter.
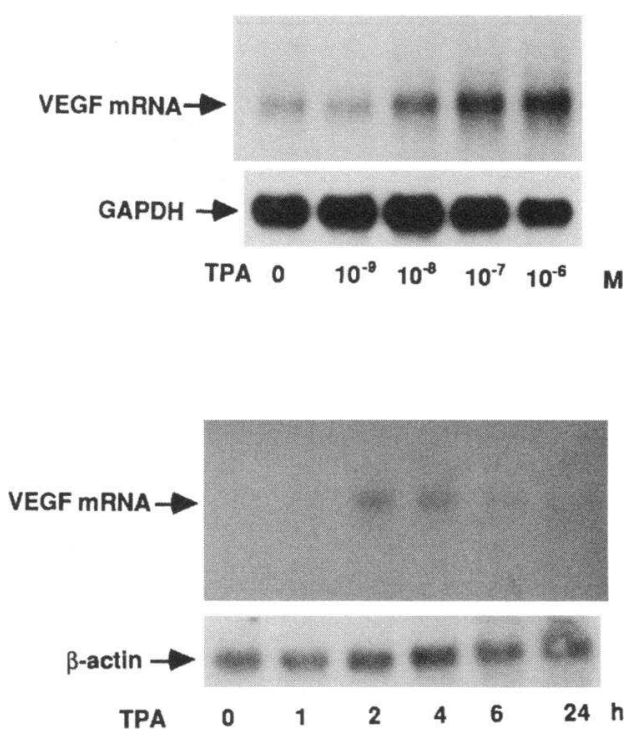

Figure 5. Effect of TPA on VEGF mRNA expression in thyroid follicles. Human thyroid follicles were cultured for $3 \mathrm{~d}$ in medium containing $1 \%$ FCS and subsequently treated with TPA $\left(0-10^{-6} \mathrm{M}\right)$ for $3 \mathrm{~h}$ (upper panel). In the other experiment, thyroid follicles were cultured for $3 \mathrm{~d}$ and treated with TPA $\left(10^{-8} \mathrm{M}\right)$ for the indicated times, from 0 to 24 $\mathrm{h}$ (lower panel). Total RNA (10 $\mu \mathrm{g} /$ lane) was subjected to RNA blot analysis with a human VEGF -cDNA probe. For comparison of RNA loading, GAPDH (upper panel) or $\beta$-actin (lower panel) probe was hybridized to the same filter.

mRNA expression in a concentration-dependent manner (Fig. 6).

Effect of protein kinase A stimulators on VEGF mRNA expression. When thyroid follicles were cultured in medium supplemented with bTSH $(10 \mu \mathrm{U} / \mathrm{ml})$ and various concentrations of FCS for the first $3 \mathrm{~d}$, bTSH markedly stimulated $V E G F$ mRNA expression at lower FCS concentrations $(0.5-2 \%)$, but the stimulatory effect of bTSH was abolished at higher FCS concentrations (5\%) (Fig. 7, upper panel). Therefore, subsequent experiments were performed using thyroid follicles cultured with $1 \%$ FCS or serum-free medium supplemented with $0.2 \%$ BSA and insulin and/or TSH.

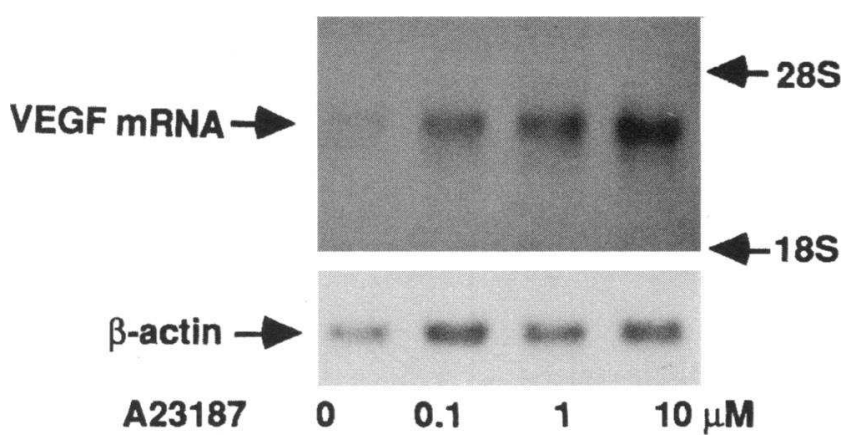

Figure 6. Effect of a calcium ionophore, A23187, on VEGF mRNA expression. Human thyroid follicles were cultured in medium containing $1 \%$ FCS for $3 \mathrm{~d}$ and subsequently treated with A23187 $(0-10 \mu \mathrm{M})$ for $3 \mathrm{~h}$. Total RNA ( $10 \mu \mathrm{g} / \mathrm{lane}$ ) was subjected to RNA blot analysis with a human $V E G F$ cDNA probe. For comparison of RNA loading, a $\beta$ actin probe was hybridized to the same filter. 

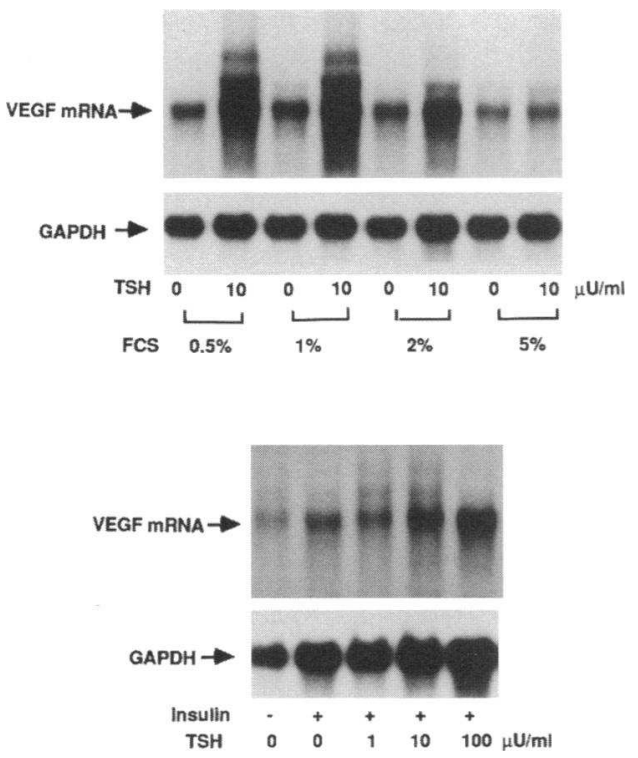

Figure 7. Effect of TSH on VEGF mRNA expression in thyroid follicles. Human thyroid follicles were cultured in medium containing bTSH ( 10 $\mu \mathrm{U} / \mathrm{ml}$ ) and various concentrations of FCS $(0.5-5 \%)$ for the first $3 \mathrm{~d}$. Total RNA ( $10 \mu \mathrm{g} /$ lane) was subjected to RNA blot analysis with a human VEGF cDNA probe (upper panel). In the other experiments, human thyroid follicles were cultured in serum-free medium supplemented with $0.2 \%$ BSA for $3 \mathrm{~d}$. Then, the thyroid follicles were cultured in serum-free medium supplemented with $0.2 \%$ BSA, insulin $(0.04 \mu \mathrm{g} /$ $\mathrm{ml}$ ), and various concentrations of bTSH $(1-100 \mu \mathrm{U} / \mathrm{ml})$ for an additional $3 \mathrm{~d}$. Total RNA ( $20 \mu \mathrm{g} /$ lane) was subjected to RNA blot analysis with a human VEGF cDNA probe (lower panel). For comparison of RNA loading, a GAPDH probe was hybridized to the same filter. When hybridization signals on the blots were analyzed quantitatively by densitometric scanning of autoradiograms, $V E G F$ mRNA expression shown in the lower panel (control:1) increased 1.5-(insulin/-), 1.6- (insulin/ TSH $1 \mu \mathrm{U} / \mathrm{ml}$ ), 2.2- (insulin/TSH $10 \mu \mathrm{U} / \mathrm{ml}$ ), and 2.0-fold (insulin/ TSH $100 \mu \mathrm{U} / \mathrm{ml}$ ).

After preculture of thyroid follicles in serum-free medium without TSH for $3 \mathrm{~d}$, time-course studies revealed that the stimulatory effect of bTSH on VEGF mRNA expression was not distinctly evident within $1-6 \mathrm{~h}$ at physiological concentrations $(1-100 \mu \mathrm{U} / \mathrm{ml})$, although in two of six experiments, bTSH stimulated $V E G F$ mRNA expression slightly at $2 \mathrm{~h}$ of incubation. However, when thyroid follicles were cultured with bTSH in the presence of insulin for 1-3 d, TSH stimulated VEGF mRNA expression in a concentration-dependent manner (Fig. 7, lower panel).

This was also the case with IgG obtained from serum of patients with Graves' disease. Graves' IgG stimulated VEGF mRNA in human thyroid follicles cultured for $2 \mathrm{~d}$ (Fig. 8).

Dibutyryl cAMP also mimicked the effect of TSH and Graves' IgG, increasing VEGF mRNA expression at 0.05-1 $\mathrm{mM}$ (Fig. 9), at which concentration thyroid hormonogenesis was substantially stimulated, as described previously (14).

When thyroid follicles were cultured in medium supplemented with $1 \%$ FCS, bTSH $(100 \mu \mathrm{U} / \mathrm{ml})$, and $\mathrm{H} 7(20 \mu \mathrm{M})$ for $3 \mathrm{~d}$, the TSH-induced expression of $V E G F$ mRNA was substantially inhibited by $\mathrm{H} 7$ (Fig. 10), suggesting that TSH stimulates $V E G F$ mRNA expression at least partly through protein kinase $C$ pathway.

Expression of flt-1 in cultured thyroid follicles. Thyroid

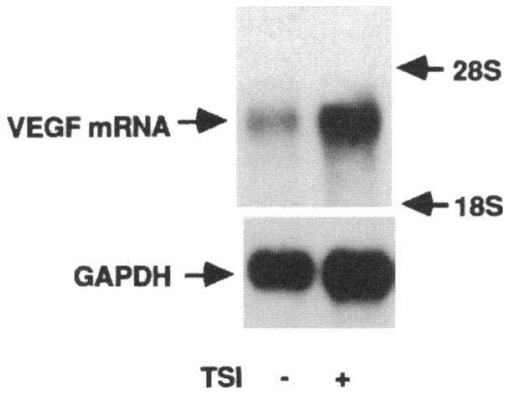

Figure 8. Effect of Graves' IgG on VEGF mRNA expression in thyroid follicles. Human thyroid follicles were cultured in medium containing $1 \%$ FCS for $3 \mathrm{~d}$ and subsequently treated with Graves' IgG (thyroid-stimulating Ig [TSI] $)(100 \mu \mathrm{l} / \mathrm{ml})$ for 2 d. Total RNA $(10 \mu \mathrm{g} /$

lane) was subjected to RNA blot analysis with a human VEGF cDNA probe. For comparison of RNA loading, a GAPDH probe was hybridized to the same filter. When hybridization signals on the blots were analyzed quantitatively by densitometric scanning of autoradiograms, VEGF mRNA expresion (control:1) increased 3.0-fold in the thyroid-stimulating Ig-treated thyroid follicles.

follicles cultured in serum-free medium supplemented with $0.2 \%$ BSA, insulin $(1 \mu \mathrm{g} / \mathrm{ml})$, and bTSH $(10 \mu \mathrm{U} / \mathrm{ml})$ for $3 \mathrm{~d}$, expressed VEGF mRNA but not $f t-1$ mRNA (Fig. 11). In contrast, human placental tissue obtained at a normal delivery showed high expression of $f t-1$ mRNA, as reported previously (6).

Expression of VEGF and fit family mRNAs in rat thyroid glands in vivo. In thiouracil-fed rats, serum $\mathrm{T}_{3}$ and $\mathrm{T}_{4}$ levels were decreased rapidly: serum $\mathrm{T}_{3}$ level (day $0 ; 72.0 \pm 13.0 \mathrm{ng}$ / $\mathrm{dl}, n=5$, means $\pm \mathrm{SD})$ was lowered to $42.9 \pm 11.1 \mathrm{ng} / \mathrm{dl}(P$ $<0.05$ ) by day 3 , accompanied by a significant increase in the serum TSH level (day $3,1.42 \pm 0.24 \mathrm{ng} / \mathrm{ml}$, means $\pm \mathrm{SD}, n=5$; day $0,0.66 \pm 0.15 \mathrm{ng} / \mathrm{ml}, P<0.05$ ). After $7 \mathrm{~d}$, serum $\mathrm{T}_{4}$ (day $0,3.9 \pm 0.6 \mu \mathrm{g} / \mathrm{dl})$ was undetectable $(<1 \mu \mathrm{g} / \mathrm{dl})$, and serum TSH increased steadily (day $7,2.1 \pm 0.54$; day $14,4.3 \pm 0.90$; day $21,4.5 \pm 1.0$; day $28,6.6 \pm 2.7 \mathrm{ng} / \mathrm{ml}, n=5$, means $\pm S D$ ), accompanied by enlargement of the thyroid glands. However, the thyroid glands were not weighed to facilitate rapid preparation of the RNA. Consistent with the in vitro findings, VEGF mRNA was expressed in the thyroid gland of control rats. $V E G F$ mRNA expression increased to a greater extent on days 3-7, then decreased to the control level by day 14 (Fig. $12 \mathrm{~A}$ ).

As expected, thyroid glands of control rats expressed mRNA of VEGF receptors, $f t-1$ and its related gene $K D R / f l k-1$. Interestingly, both $f t t-1$ and $K D R / f l k-1$ mRNAs were also increased on days 3-7, and decreased gradually to the control level on days 14-28 (Fig. 12, $B$ and $C$ ). The response of $K D R / f l k-1$ was slightly slower than that of $f t-1$ and highest at day 7 .

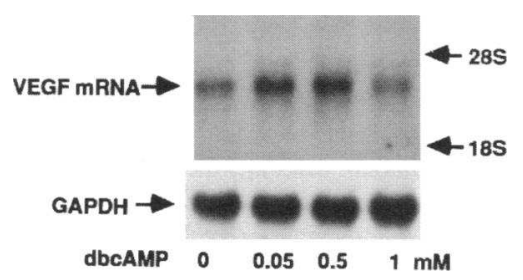

Figure 9. Effect of dibutyryl cAMP on $V E G F$ mRNA expression. Human thyroid follicles were cultured in medium containing $1 \%$ FCS for 3 $\mathrm{d}$ and subsequently treated with dibutyryl cAMP $(0-1 \mathrm{mM})$ for 3 h. Total RNA ( $10 \mu \mathrm{g} /$ lane) was subjected to RNA blot analysis with a human VEGF cDNA probe. For comparison of RNA loading, a GAPDH probe was hybridized to the same filter. 


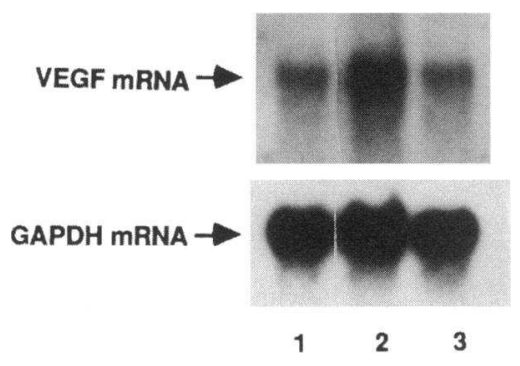

man $V E G F$ cDNA probe. For comparison of RNA loading, a GAPDH probe was hybridized to the same filter. When hybridization signals on the blots were analyzed quantitatively by densitometric scanning of autoradiograms, VEGF mRNA expression (control:1) increased 3.3and 1.1-fold in the TSH- and TSH/H-7-treated thyroid follicles, respectively. Lane 1, control; lane 2, TSH; lane 3, TSH + H7.

\section{Discussion}

It has been proposed from in vivo studies that thyroid angiogenesis during thyroid enlargement may be due to paracrine mitogenic factors released by epithelial thyroid cells: angiogenesis factor(s) may be produced within the thyroid gland and diffuse into the blood vessels, causing mitosis of capillary endothelial cells $(15,23-25)$. Using human thyroid follicles in suspension culture, which incorporate ${ }^{125} \mathrm{I}$ and secrete ${ }^{125} \mathrm{I}_{-} \mathrm{T}_{4}$ and ${ }^{125} \mathrm{I}-\mathrm{T}_{3}$ into the medium in response to TSH and Graves' IgG, we demonstrated that both thyrotropic factors increased the level of $V E G F$ mRNA in a time- and dose-dependent manner. Since VEGF is a secretable angiogenesis factor capable of specifically stimulating the proliferation of endothelial cells $(2-11)$, it is reasonable to speculate that VEGF, produced in response to

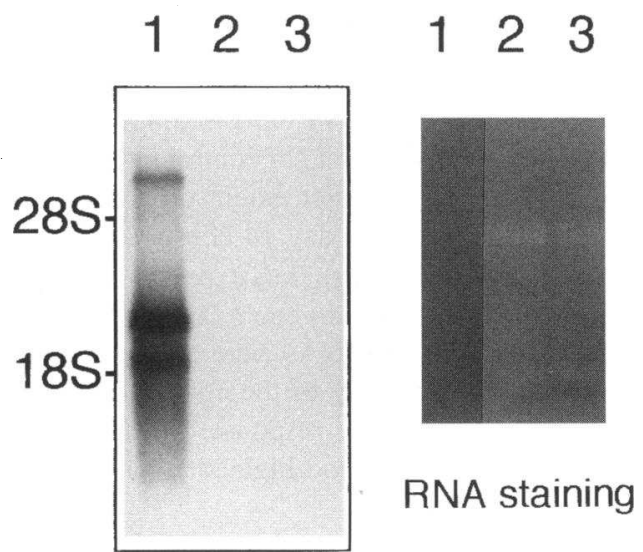

Figure 11. Expression of $f t-1 \mathrm{mRNA}$ in human placenta and cultured human thyroid follicles. Human thyroid follicles were cultured in serumfree medium supplemented with $0.2 \%$ BSA, bTSH $(10 \mu \mathrm{U} / \mathrm{ml})$, and insulin $(1 \mu \mathrm{g} / \mathrm{ml})$ for $3 \mathrm{~d}$. Then, total RNA was prepared as described in Methods. mRNA was prepared from human placenta (6). The mRNA ( $1 \mu \mathrm{g}$, lane 1 ) and total RNA from human thyroid follicles (10 $\mu \mathrm{g}$; lanes 2 and 3) were subjected to RNA blot analysis with human fit-1 cDNA as a probe (left). Ethidium bromide staining of RNA samples are shown (right). At about the 8-kb band located above the 28S rRNA is the full-length $f t-1 \mathrm{mRNA}$ and the two strong bands of 2.2 and 3.0 $\mathrm{kb}$ are the $f t-1$ short transcripts which encode only the extracellular domain of the Flt-1 receptor ( right, lane 1) (6). These short transcripts are highly expressed in placenta but low in most of other tissues (6).

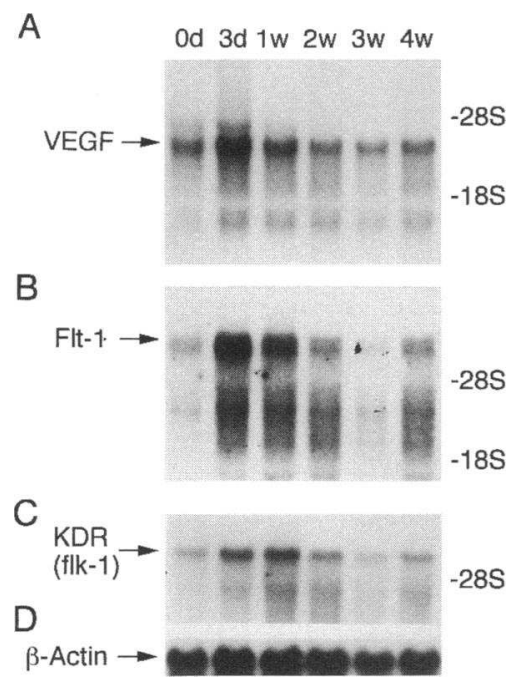

Figure 12. Expression of VEGF and fit family mRNAs in thiouracil-fed rats. Rats were fed a low iodine rat chow containing $0.25 \%$ thiouracil for $28 \mathrm{~d}$. On days 3,7 , 14,21 , and 28 , blood was taken. Then, the thyroid gland was immediately removed and RNA was prepared. About $10 \mu \mathrm{g}$ of total RNA was analyzed by Northern blotting with rat $V E G F, f l t-1, K D R / f l k$ 1 , and $\beta$-actin cDNAs as probes. The same RNA filter was sequentially hybridized with these probes after removal of the previous probe. After hybridization with each probe at $1 \times 10^{6} \mathrm{cpm} / \mathrm{ml}$, the filter was washed and exposed to x-ray film (Fuji Photo Film Co., Tokyo, Japan) for $4 \mathrm{~d}$ (VEGF probe), $7 \mathrm{~d}$ (flt-1 or KDR/flk-1 probe), and $1 \mathrm{~d}$ ( $\beta$-actin probe). The ratios of $V E G F, f l t-1$, and $K D R / f l k-1 \mathrm{mRNAs}$ to the control $\beta$-actin mRNAs (1.0 at 0-d) increased 3.8-, 1.1-, 0.8-, and 1.0-fold; 4.6-, 1.5-, 1.2-, 1.0-, and 1.0-fold; and 2.0-, 2.3-, 1.0-, 1.0-, and 1.0-fold; respectively, on 3-d, 1-, 2-, 3-, and 4-wk.

TSH receptor stimulators, is responsible for proliferation of endothelial cells that surround thyroid follicles, leading to enlargement of blood vessels.

Indeed, Greil et al. (26) have reported that porcine thyroid follicles produce an endothelial cell growth factor with a mol wt of $\sim 15,000$, which binds to heparin-Sepharose. Although the thyroid gland contains bFGF (27), the protein lacks a signal peptide, suggesting that FGF or FGF-related angiogenesis factors become active only when cells are damaged or destroyed. In contrast, our in vitro findings suggest that human thyroid follicles produce $V E G F$ mRNA in response to various factors (insulin, protein kinase $\mathrm{A}$ and $\mathrm{C}$ activators) and secrete immunoreactive VEGF into the culture medium, suggesting that VEGF is the most likely candidate for the angiogenesis factor produced in the thyroid gland. At this moment, however, we cannot completely rule out a minor possibility that the antibodies other than anti-TSH-receptor antibody in Graves' IgG also contribute in a part to this process.

Previously, light- and electron-microscopic studies by Wollman et al. $(15,23-25)$ demonstrated that thyroid enlargement in thiouracil-fed rats started with endothelial cell proliferation on days 3-5. Furthermore, it was shown that $\left[{ }^{3} \mathrm{H}\right]$ thymidine incorporation into endothelial cells of capillaries, veins, and arteries was initiated within $48 \mathrm{~h}$ of thiouracil feeding (28). The labeling index (percentage of labeled nuclei in endothelial cells) peaked at days $2-5(15-17 \%)$ and decreased gradually thereafter but was still greater than in the control on day 20 . During this time, capillaries seemed to fuse with each other, causing further enlargement of blood vessels. In keeping with these histomorphological findings, our in vivo data indicated that the levels of both $V E G F$ and $V E G F$ receptor ( $f l$ family) mRNAs increased on days 3-7 in the thyroid gland of thiouracil-fed rats, suggesting that VEGF stimulates endothelial proliferation. A decrease in $V E G F$ mRNA expression by day 14 was 
almost consistent with, but slightly earlier than, the decreased labeling index observed in the thiouracil-fed rats (28). A slower decrease in the mitotic index might be due to a release of residual VEGF stored within the tissues or a minor difference in experimental conditions.

Under the experimental conditions we used, human thyroid follicles in suspension culture are devoid of endothelial cells (12). Therefore, it is reasonable for thyroid follicles to express VEGF mRNA but not fit mRNA. As expected, however, rat thyroid glands, composed of endothelial cells and epithelial cells, expressed fit family mRNAs, which also increased on day 3, when VEGF mRNA was maximally increased. VEGF receptors (Flt family) are expressed both in endothelial cells participating in neovascularization as well as in quiescent endothelium (29). Since VEGF specifically stimulates endothelial cell proliferation via activation of its receptors (Flt family: Flt1 and $\mathrm{KDR} / \mathrm{flk}-1$ tyrosine kinases $)(8,21,30,31)$, the increase in $f t$ family mRNA expression probably reflects proliferation of endothelial cells in the thyroid. Interestingly, the levels of $V E G F$ and $f t$ family mRNAs were decreased by days 14-28, when endothelial cells ceased to proliferate and capillaries began to fuse with each other (15).

At the present time, the regulatory mechanism of VEGF expression in endocrine tissues is poorly understood. We have demonstrated that treatment of human thyroid follicles with TPA and a calcium ionophore (A23187) readily (within 2-4 h) induces a significant increase in $V E G F$ mRNA, suggesting that $V E G F$ mRNA expression is regulated by a protein kinase $\mathrm{C}$-mediated signal transduction pathway, as reported in preadipocytes and vascular smooth muscle cells $(32,33)$. Furthermore, we have demonstrated that dibutyryl cAMP, TSH, and Graves' IgG also induced $V E G F$ mRNA expression, suggesting that both thyrotropic factors stimulate the expression of $V E G F$ mRNA at least in part by the cAMP-dependent protein kinase A pathway. Analogous findings have also been reported for PTH in osteoblast-like cells (34). Since TSH and Graves' IgG stimulate both the protein kinase $\mathrm{A}$ and protein kinase $\mathrm{C}$ pathways (35-39), it is reasonable to speculate that $\mathrm{TSH}$ as well as Graves' IgG stimulates VEGF mRNA expression by acting on TSH receptors through both pathways. It is likely that VEGF, synthesized in thyrocytes in response to TSH or Graves' IgG, is secreted and binds to Flt receptors on endothelial cells, thus stimulating endothelial cell proliferation and leading to hypervascularity of thyroid glands in patients with Graves' disease. Other physiological stimuli that increase VEGF mRNA are estrogen in the uterus (39), hypoxia in cultured cells (40), PGE, and $1,25(\mathrm{OH})_{2} \mathrm{D}_{3}$ in osteoblast-like cells $(34,41)$.

Recently, Yamane et al. (21) demonstrated in rat liver that parenchymal cells produce VEGF, which, once secreted, binds to Flt receptors on sinusoidal endothelial cells, leading to their proliferation. Reciprocally, nonparenchymal cells produce hepatocyte growth factor, which binds to the Met receptor on hepatocytes, causing hepatocyte proliferation. Thus, there is a communication system between hepatocytes and sinusoidal endothelial cells in the liver through VEGF and the Flt family. By analogy with the liver, the thyroid gland also may possess a communication system between parenchymal thyrocytes and endothelial cells, via production of VEGF by thyrocytes and subsequent stimulation of Flt receptors on endothelial cells, leading to proliferation of endothelial cells. Whether or not endothelial cells in the thyroid produce thyroid growth factors remains to be studied.
Interestingly, the stimulatory effect of TSH on VEGF mRNA expression was abolished when thyroid follicles were cultured in medium supplemented with a high FCS concentration $(5-10 \%)$, in which thyroid follicles were not capable of synthesizing thyroid hormone in response to TSH. These findings are consistent with those in the ovary, testis, and adrenal glands, in which all cell types expressing $V E G F$ mRNA are steroidogenic and/or steroid responsive (42), suggesting that hormonogenesis and angiogenesis in endocrine tissues are closely regulated.

Finally, it should be pointed out that in the thyroid gland of patients with Graves' disease, lymphatic fluid is produced profusely and flows into the retroorbital region (43). This phenomenon may be due partly to overproduction of VEGF in the thyroid, since the angiogenesis factor is also a strong vascular permeability factor $(44-46)$.

In summary, we have demonstrated for the first time that thyroid parenchymal cells of the thyroid gland express $V E G F$ mRNA but not $f t$ mRNA, and that VEGF mRNA expression is stimulated by TSH and Graves' IgG, via the protein kinase $\mathrm{A}$ and $\mathrm{C}$ pathways. We have also shown that $V E G F$ and $f t$ mRNA expression is increased in the enlarged thyroid gland of thiouracil-fed rats. These in vitro and in vivo findings may account at least in part for the hypervascularity of the thyroid glands seen in patients with Graves' disease.

\section{Acknowledgments}

We thank Drs. A. Sawano and Y. Ishii (Department of Genetics, Institute of Medical Science, University of Tokyo) for excellent technical assistance and helpful discussions.

This work was supported by a grant-in-aid for scientific research from the Ministry of Education, Science, and Culture of Japan $(04253204,06671060)$, and a research grant from Institute for Growth Science in Japan, Shinjuku-ku, Tokyo.

\section{References}

1. Ingbar, S. H., and K. A. Woeber. The Thyroid. 1981. In Williams Textbook of Endocrinology. 6th ed. J. D. Wilson and D. W. Foster, editors. W. B. Saunders Co., Philadelphia. 117-247.

2. Folkman, J., and Y. Shing. 1992. Angiogenesis. J. Biol. Chem. 267:10931 10934.

3. Ferrara, N., K. Houck, L. Jakeman, and D. W. Leung. 1992. Molecular and biological properties of the vascular endothelial growth factor family of proteins. Endocr. Rev. 13:18-32.

4. Connolly, D. T., D. M. Heuvelman, R. Nelton, J. V. Olander, B. L. Eppley, J. J. Delfino, N. R. Siegel, R. M. Leimgruber, and J. Feder. 1989. Tumor vascular permeability factor stimulates endothelial cell growth and angiogenesis. J. Clin. Invest. 84:1470-1478.

5. Leung, D. W., G. Cachianes, W. J. Kuang, D. V. Goeddel, and N. Ferara. 1989. Vascular endothelial growth factor in a secreted angiogenic mitogen. Science (Wash. DC). 246:1306-1309.

6. Shibuya, M., S. Yamaguchi, A. Yamane, T. Ikeda, A. Tojo, H. Matsushime, and M. Satoh. 1990. Nucleotide sequence and expression of a novel human receptor-type tyrosine kinase $(f l t)$ closely related to the fms family. Oncogene. 8:519-524.

7. Shibuya, M. 1995. A review on the role of VEGF-Flt receptor system in normal and tumor angiogenesis. Adv. Cancer Res. 67:in press.

8. De Vries, G., J. A. Escobedo, H. Ueno, K. Houck, N. Ferrara, and L. T. Williams. 1992. The fms-like tyrosine kinase, a receptor for vascular endothelial growth factor. Science (Wash. DC). 255:989-991.

9. Jakeman, L. B., J. Winer, G. L. Bennett, C. A. Altar, and N. Ferrara. 1992. Binding sites for vascular endothelial growth factor are localized on endothelial cells in adult rat tissues. J. Clin. Invest. 89:244-253.

10. Gospodarowicz, L. E., J. A. Abraham, and J. Schilling. 1989. Isolation and characterization of a vascular endothelial mitogen produced by pituitaryderived folliculo-stellate cells. Proc. Natl. Acad. Sci. USA. 86:7311-7315.

11. Conn, G., D. D. Soderman, M. Schaeffer, M. Wile, V. B. Hatcher, and 
K. A. Thomas. 1990. Purification of a glycoprotein vascular endothelial cell mitogen from a rat glioma-derived cell line. Proc. Natl. Acad. Sci. USA. 87:1323 1327.

12. Sato, K., T. Satoh, K. Shizume, M. Ozawa, D. Han, H. Imamura, T Tsushima, H. Demura, Y. Kanaji, Y. Ito, et al. 1990. Inhibition of ${ }^{125}$ I organification and thyroid hormone release by interleukin-1, tumor necrosis factor- $\alpha$, and interferon- $\gamma$ in human thyrocytes in suspension culture. J. Clin. Endocrinol. \& Metab. 70:1735-1743.

13. Sato, K., K. Yamazaki, K. Shizume, Y. Yamakawa, T. Satoh, H. Demura Y. Kanaji, Jr., T. Obara, Y. Fujimoto, M. Aiba, et al. 1993. Pathogenesis of autoimmune hypothyroidism induced by lymphokine-activated killer (LAK) cell therapy: in vitro inhibition of human thyroid function by interleukin-2 in the presence of autologous intrathyroidal lymphocytes. Thyroid. 3:179-188.

14. Yamazaki, K., K. Sato, K. Shizume, Y. Kanaji, Y. Ito, T. Obara, T. Nakagawa, T. Koizumi, and R. Nishimura. 1995. Potent thyrotropic activity of human chorionic gonadotropin variants in terms of ${ }^{125} \mathrm{I}$ incorporation and de novo-synthesized thyroid hormone release in human thyroid follicles. J. Clin. Endocrinol. \& Metab. 80:473-479.

15. Wollman, S. H., J. P. Herveg, J. D. Zelig, and L. E. Ericson. 1978. Blood capillary enlargement during the development of thyroid hyperplasia in the rat. Endocrinology. 102:2306-2314.

16. Nitsch, L., and S. H. Wollman. 1980. Suspension culture of separated follicles consisting of differentiated thyroid epithelial cells. Proc. Natl. Acad. Sci. USA. 77:472-476.

17. Sato, K., and J. Robbins. 1981. Thyroid hormone metabolism in primary cultured rat hepatocytes. Effects of glucose, glucagon, and insulin. J. Clin. Invest. 68:475-483.

18. Nohtomi, K., K. Sato, K. Shizume, Y. Yamazaki, H. Demura, K. Hosoda, Y. Murata, and H. Seo. 1994. Stimulation by interleukin-4 of cell proliferation and mRNA expression of alkaline phosphatase and collagen type I in human osteoblast-like cells of trabecular bone. Bone Miner. 27:69-79.

19. Chomczynski, P., and N. Sacchi. 1987. Single-step method of RNA isolation by acid guanidinium thiocyanate-phenol-choloroform extraction. Anal. Biochem. 162:156-159.

20. Keck, J. P., S. C. Hauser, G. Krivi, K. Sanzo, T. Warren, J. Feder, and D. T. Connolly. 1989. Vascular permeability factor, and endothelial cell mitogen related to PDGF. Science (Wash. DC). 246:1309-1312.

21. Yamane, A., L. Seetharam, S. Yamaguchi, N. Gotoh, T. Takahashi, G. Neufeld, and M. Shibuya. 1994. A new communication system between hepatocytes and sinusoidal endothelial cells in liver through vascular endothelial growth factor and Flt tyrosine kinase receptor family (Flt-1 and KDR/Flk-1). Oncogene. 9:2683-2690.

22. Miyazaki, T., M. Sato, Y. Murata, and H. Seo. 1995. Factor(s) present in sera from patients on long-term hemodialysis increase (s) mRNAs for collagenase and stromelysin in synovial cells. Am. J. Nephrol. 15:48-56.

23. Ericson, L. E., and S. H. Wollman. 1980. Ultrastructural aspects of capillary fusion during the development of thyroid hyperplasia. J. Ultrastruct. Res. 72:300-315.

24. Erickson, L. R., and S. H. Wollman. 1980. Increase in the rough endoplasmic reticulum in capillary endothelial cells and pericytes in hyperplastic rat thyroid glands. Endocrinology. 107:732-737.

25. Zeligs, J. D., and S. H. Wollman. 1981. Ultrastructure of cytokinesis in blood capillary endothelial cells in thyroid gland in vivo. J. Ultrastruct. Res. 75:291-299.

26. Greil, W., M. Rafferzeder, G. Bechtner, and R. Gärtner. 1989. Release of an endothelial cell growth factor from cultured porcine thyroid follicles. Mol. Endocrinol. 3:858-867.

27. Emoto, N. O. Isozaki, M. Arai, H. Murakami, K. Shizume, A. Baird, T. Tsushima, and H. Demura. 1991. Identification and characterization of basic fibroblast growth factor in porcine thyroids. Endocrinology. 128:58-64.

28. Smeds, S., and S. H. Wollman. 1983. ${ }^{3} \mathrm{H}$-Thymidine labelling of endothelial cells in thyroid arteries, veins and lymphatics during thyroid stimulation. $L a b$. Invest. 48:285-291.

29. Jakeman, L. B., M. Armanini, H. S. Phillips, and N. Ferrara. 1993. Developmental expression of binding sites and messenger ribonucleic acid for vascular endothelial growth factor suggests a role for this protein in vasculogenesis and angiogenesis. Endocrinology. 133:848-859.

30. Millauer, B., S. Wizigmann-Voos, H. Schnärch, R. Martinez, M. P. H. Mäller, W. Risau, and A. Ullrich. 1993. High-affinity VEGF binding and developmental expression suggest that $F l k-1$ is a major regulator of vasculogenesis and angiogenesis. Cell. 72:835-846.

31. Seetharam, L., N. Gotoh, Y. Maru, G. Neufeld, S. Yamaguchi, and M. Shibuya. 1995. A unique signal transduction from FLT tyrosine kinase, a receptor for vascular endothelial growth factor VEGF. Oncogene. 10:135-147.

32. Claffey, K. P., W. O. Wilkinson, and B. M. Spiegelman. 1992. Vascular endothelial growth factor: regulation by cell differentiation and activated second messenger pathways. J. Biol. Chem. 267:16317-16322.

33. Tischer, E., R. Mitchell, T. Hartman, M. Silva, D. Gospodarowicz, J. C. Fiddes, and J. A. Abraham. 1991. The human gene for vascular endothelial growth factor. Multiple protein forms are encoded through alternative exon splicing. $J$. Biol. Chem. 266:11947-11954.

34. Harada, S., J. A. Nagy, K. A. Sullivan, K. A. Thomas, N. Endo, G. A. Rodan, and S. B. Rodan. 1994. Induction of vascular endothelial growth factor expression by prostaglandin $\mathrm{E}_{2}$ and $\mathrm{E}_{1}$ in osteoblasts. J. Clin. Invest. 93:24902496.

35. Dumont, J. E., F. Lamy, P. Roger, and C. Maenhaut. 1992. Physiological and pathological regulation of thyroid cell proliferation and differentiation by thyrotropin and other factors. Physiol. Rev. 72:667-697.

36. Van Sande, J., E. Raspe, J. Perret, C. Lejeune, C. Maenhaut, G. Vassart, and J. E. Dumont. 1990. Thyrotropin activates both the cyclic AMP and the PIP2 cascades in CHO cells expressing the human cDNA of TSH receptor. Mol. Cell. Endocrinol. 74:R1-R6.

37. Van Sande, J., C. Lejeune, M. Ludgate, D. S. Munro, G. Vassart, J. E. Dumont, and J. Mockel. 1992. Thyroid stimulating immunoglobulins, like thyrotropin activate both the cyclic AMP and the PIP2 cascade in CHO cells expressing the TSH receptor. Mol. Cell. Endocrinol. 88:R1-R2.

38. Kosugi, S., F. Okajima, T. Ban, A. Hidaka, A. Shenkers, and L. D. Kohn. 1992. Mutation of alanine 623 in the third cytoplasmic loop of the rat thyrotropin receptor results in the phosphoinositide but not cAMP signal induced by TSH and receptor antibodies. J. Biol. Chem. 267:24153-24156.

39. Cullinan-Bove, K., and R. D. Koos. 1993. Vascular endothelial growth factor-vascular permeability factor expression in the rat uterus: rapid stimulation by estrogen correlates with estrogen-induced increases in uterine capillary permeability and growth. Endocrinology. 133:829-837.

40. Shewiki, D., A. Itin, D. Soffer, and E. Keshet. 1992. Vascular endothelial growth factor induced by hypoxia mediates hypoxia-initiated angiogenesis. Nature (Lond.). 359:843-845.

41. Wang, D. S., K. Sato, K. Yamazaki, K Nohtomi, K Shizume, H. Demura, A. Sawano, Y. Ishii, S. Yamaguchi, and M. Shibuya. 1994. Vascular endothelial growth factor (VEGF) mRNA expression in human osteoblast-like cells. Regulation by protein kinase $\mathrm{C}$, insulin-like growth factor and vitamin D. The 10th AsiaOceania Congress of Endocrinology, October 30-November 3, 1994, Beijing, China. (Abstr.).

42. Shweiki, D., A. Itin, G. Neufeld, H. Gitay-Goren, and E. Keshet. 1993. Patterns of expression of vascular endothelial growth factor (VEGF) and VEGF receptors in mice suggest a role in hormonally regulated angiogenesis. J. Clin. Invest. 91:2235-2243.

43. Kriss, J. P., J. Konishi, and M. Herman. 1975. Studies on the pathogenesis of Graves' ophthalmopathy (with some related observations regarding therapy). Recent Prog. Horm. Res. 31:533-566.

44. Senger, D. R., C. A. Perruzzi, J. Feder, and H. F. Dvorak. 1986. A highly conserved vascular permeability factor secreted by a variety of human and rodent tumor cell lines. Cancer Res. 46:5629-5632.

45. Plate, K., G. Breier, H. A. Welch, and W. Risau. 1992. Vascular endothelial growth factor is a potential tumour angiogenesis factor in human gliomas in vivo. Nature (Lond.). 359:845-848.

46. Yeo, K-T., H. H. Wang, J. A. Nagy, T. M. Sioussat, S. R. Ledbetter, A. J. Hoogewerf, Y. Zou, E. M. Masse, D. R. Senger, H. F. Dvorak, and T.-K. Yeo 1993. Vascular permeability factor (vascular endothelial growth factor) in guinea pig and human tumor and inflammatory effusions. Cancer Res. 53:2912-2918. 